\title{
Health Risks Assessment of Habitants in Extreme Continental Climate
}

\author{
Daria Chernykh $^{1,2}$, Olga Taseiko ${ }^{1,2}$, Milosevic Hranislav $^{3}$, Stefan Panic $^{3}$ \\ ${ }^{1}$ Institute of Computational Technologies SB RAS, Krasnoyarsk Branch office, 660049, Krasnoyarsk, Russia \\ ${ }^{2}$ Reshetnev Siberian State University of Science and Technology, 660037, Krasnoyarsk, Russia \\ ${ }^{3}$ Faculty of Natural Science and Mathematics, University of Pristina, 38220, Kosovska Mitrovica, Serbia
}

doi: https://doi.org/10.21467/abstracts.93.4

\begin{abstract}
Periods of extremely cold weather which leads to a considerable health risk especially for vulnerable groups of people are quite common nowaday not only in Siberia but in the European Region. Health and social services register the growth of a number of seeking medical advice caused by the various health effects associated with extreme cold conditions. The increasing mortality mainly among the elderly, suffering from chronic diseases of the cardiovascular or respiratory systems, is associated with the effect of abnormal temperatures [1-2]. The climate of Krasnoyarsk territory can be described as highly continental influenced climate with hot summer (with temperature to $+36^{\circ} \mathrm{C}$ ) and cold winter (with temperature to $-43^{\circ} \mathrm{C}$ ) [3]. An analysis of the effect of cold waves and temperature contrasts in a short time on the population health is relevant due to the existing climatic features.
\end{abstract}

Materials and methods. To assess the meteorological parameters, we used data from meteorological station, which is the background for Krasnoyarsk city [4]. The identification of cold waves for the cities of Krasnoyarsk territory was carried out by the method of long-term distributions of average daily temperatures [5]. Temperature contrasts were evaluated as maximal temperature change during the whole day $(24 \mathrm{~h})$.

To solve this problem, a database of mortality indicators was used, provided by the Territorial Authority of the Federal State Statistics Service for the Krasnoyarsk Region. The daily mortality rates were divided into four groups of age (0-17, 18-29, 30-64 and 65+) from the most common diseases characterized by sensitivity to climatic factors for the period from 2012 to 2014 :

diseases of the circulatory system (I10-I15, I20-I25, I44-I49, I60-I69);

diseases of the respiratory system (J00-J22, J30, J40-J45).

To assess the proportion of the population exposed to the influence of cold waves and temperature contrasts a relative risk (RR) was calculated [5]

$$
R R_{L}=\max _{j=0, \ldots, L} \frac{\sum_{i=j}^{N-1+j} M_{D+i+j}}{N M_{D+j}^{\Phi}}
$$

The results of the study. The cold waves have statistically significant influence on mortality from disease of the circulatory system for ages older 34 years and disease of the respiratory system for ages older 65 years (Table 1). The analysis of mortality relative risk caused by rapid temperature change are shown that these rates connect to diseases of the circulatory system for elderly (Table 2).

Conclusions. The study results suggest that the greatest negative impact of cold waves was established for mortality from circulatory diseases for the two groups of age (30-64 and older than 65 years). At the same time, the health risks caused by temperature contrasts exceed those for cold waves, mainly for the circulatory system.

(C) 2020 Copyright held by the author(s). Published by AIJR Publisher in "Abstracts of The Second Eurasian RISK-2020 Conference and Symposium" April 12- 19, 2020, Tbilisi, Georgia. Jointly organized by AMIR Technical Services LLC, Georgian Technical University, Institute of Geography (Kazakhstan) and Russian Institute of Petroleum Geology and Geophysics.

AijR DOI: $10.21467 /$ abstracts.93 
The Second Eurasian RISK-2020 Conference and Symposium

Table 1. Relative risk of mortality during the period to cold waves in the city of Krasnoyarsk, 2012-2014

\begin{tabular}{|c|c|c|c|}
\hline \multirow{2}{*}{ Death causes } & \multirow{2}{*}{ Groups of age, years } & \multicolumn{2}{|c|}{ Cold waves } \\
\hline & & RR & $95 \% \mathrm{CI}$ \\
\hline \multirow{4}{*}{$\begin{array}{l}\text { Diseases of the } \\
\text { circulatory system }\end{array}$} & $0-17$ & 0 & $0-0$ \\
\hline & $18-29$ & $0.01<*>$ & $0-0.12$ \\
\hline & $30-64$ & $5.33<*>$ & $4.72-5.93$ \\
\hline & $65+$ & $4.33<*>$ & $3.08-5.59$ \\
\hline \multirow{4}{*}{$\begin{array}{l}\text { Diseases of the } \\
\text { respiratory system }\end{array}$} & $0-17$ & $0.02<*>$ & $0-0.15$ \\
\hline & $18-29$ & $0.03<*>$ & $0.01-0.13$ \\
\hline & $30-64$ & 1.48 & $1.23-1.73$ \\
\hline & $65+$ & $3.19<*>$ & $2.79-3.6$ \\
\hline
\end{tabular}

$<*>-$ Dependence is statistically significant $(\mathrm{p}<0,05)$

Table 2. Relative risk of mortality from exposure to extreme temperature in Januaryin the city of Krasnoyarsk, 2012-2014

\begin{tabular}{|c|c|c|c|c|c|c|c|}
\hline \multirow{3}{*}{ Death causes } & \multirow{3}{*}{$\begin{array}{l}\text { Groups of } \\
\text { age, years }\end{array}$} & \multicolumn{6}{|c|}{ January } \\
\hline & & \multicolumn{2}{|r|}{2012} & \multicolumn{2}{|r|}{2013} & \multicolumn{2}{|r|}{2014} \\
\hline & & RR & $95 \% \mathrm{CI}$ & RR & $95 \% \mathrm{CI}$ & RR & $95 \% \mathrm{CI}$ \\
\hline \multirow{4}{*}{$\begin{array}{l}\text { Diseases of the } \\
\text { circulatory system }\end{array}$} & $0-17$ & 0.05 & $0-0.43$ & 0 & - & 0 & - \\
\hline & $18-29$ & 0.03 & $0-0.21$ & 0.02 & $0-0.05$ & 0 & - \\
\hline & $30-64$ & 5.76 & $4-6.84$ & 8.2 & $2.45-3.95$ & 8 & $2.76-5.24$ \\
\hline & $65+$ & 10.4 & $8.52-13.41$ & 4.7 & $7.63-10.87$ & 3.69 & $7.4-10.44$ \\
\hline \multirow{4}{*}{$\begin{array}{l}\text { Diseases of the } \\
\text { respiratory system }\end{array}$} & $0-17$ & 0.02 & $0-0.42$ & 0.05 & $0-0.16$ & 0.06 & $0-0.17$ \\
\hline & $18-29$ & 0.58 & $0-0.68$ & 0 & - & 0.03 & $0-0.1$ \\
\hline & $30-64$ & 1.04 & $0.05-1$ & - & - & 2.69 & $0.05-0.67$ \\
\hline & $65+$ & 1.33 & $0-0.68$ & - & - & - & - \\
\hline
\end{tabular}

Dependence is statistically significant $(\mathrm{p}<0,05)$

Acknowledgments. The reported study was funded by Russian Foundation for Basic Research, Government of Krasnoyarsk Territory, Krasnoyarsk Regional Fund of Science, to the research project: number 19-413-240013 «Risk assessment methodology caused by environmental factors on population health and mortality in industrial agglomerations».

\section{References}

Gabriel K.MA., Endlicher W.R. Urban and rural mortality rates during heat waves in Berlin and Brandenburg // Environmental pollution. 2011. Vol. 159(8-9). Pp. 2044-2050.

The impact of air temperature on mortality in Arhangelsk city in the years 1999-2008 / Zh.L. Varakina, E.D. Yurasova, B.A. Revichet al. // Human Ecology. 2011. No. 6. Pp. 28-36. [in Russian].

Shver Cz.A., Gerasimova A.S. Climate of Krasnoyarsk. Leningrad: Gidrometeoizdat. 1982. p. 231. [in Russian].

All-Russian Research Institute of Hydrometeorological Information - World Data Center. http://meteo.ru/ (Date of access 11.11.2016).

Chernykh D.A., Taseiko O.V. Assessment of the risk mortality from thermal waves in Krasnoyarsk city // Human Ecology. 2019. No. 2. Pp. 3-8. [in Russian]. 